\title{
Karakteristik Auditor Internal dan Eksternal terhadap Manajemen Laba pada Perusahaan Perbankan
}

\author{
Fauziyyah Sukmawati Kurniawan ${ }^{1}$ \\ Fakultas Ekonomi dan Bisnis \\ Universitas Airlangga, Indonesia
}

\author{
Yustrida Bernawati² \\ Fakultas Ekonomi dan Bisnis \\ Universitas Airlangga, Indonesia
}

Surel : sukmaozy@gmail.com

\section{ABSTRAK}

Manajemen laba dapat diminimalisir dengan menerapkan tata kelola yang baik. Penerapan prinsip-prinsip tata kelola yang baik dapat diwujudkan melalui: kelengkapan dan pelaksanaan tugas komite dan satuan kerja yang menjalankan fungsi pengendalian internal, serta penerapan fungsi kepatuhan, audit intern dan audit ekstern. Penelitian ini menguji pengaruh rasio sertifikasi auditor internal, realisasi audit/pemeriksaan auditor internal, jumlah auditor internal, ukuran KAP, tenure KAP, dan spesialisasi KAP terhadap manajemen laba. Penelitian ini menggunakan pendekatan kuantitatif dengan data sekunder yang berasal dari website data BEI. Teknik pengambilan sampel dilakukan dengan menggunakan metode purposive sampling. Metode analisis yang digunakan adalah analisis regresi linier berganda. Hasil analisis menunjukkan bahwa variabel jumlah auditor internal, ukuran $\mathrm{KAP}$, dan tenure $\mathrm{KAP}$ berpengaruh signifikan terhadap manajemen laba perusahaan perbankan. Variabel sertifikasi, realisasi pemeriksaan auditor internal, dan spesialisasi KAP tidak berpengaruh signifikan terhadap manajemen laba perusahaan perbankan.

Kata Kunci: Manajemen Laba; Auditor Internal; Auditor Eksternal.

\section{The Effect of Internal Auditors and External Auditors on Profit Management in Banking Companies}

\begin{abstract}
Earnings management can be minimized by implementing good governance. The principles of good governance can be realized through: completeness and implementation of the committee's duties that carry out the internal control function, as well as the implementation of the audit function, and the implementation of the audit. This study shows the effect of the ratio of internal auditor certification, realization of internal auditors I audits, number of internal auditors, size of KAP, tenure of KAP, and KAP specialists on earnings management.. This study uses a quantitative approach with secondary data derived from the IDX website data. The sampling technique was carried out using a purposive sampling method. The analytical method used is multiple linear regression analysis. The results of the analysis show that the variables of the number of internal auditors, size of KAP, and tenure of KAP have a significant effect on earnings management of banking companies. Variables of certification, realization of internal auditors, and KAP specialists have no significant effect on earnings management of banking companies.
\end{abstract}

Keywords: Earning Management; Internal Auditor; External Auditor.

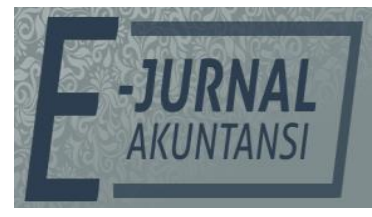

e-ISSN 2302-8556

Vol. 30 No. 12

Denpasar, Desember 2020

Hal. 3176-3188

DOI:

10.24843/EJA.2020.v30.i12.p14

PENGUTIPAN:

Kurniawan, F.S. \&

Bernawati, Y. (2020).

Karakteristik Auditor

Internal dan Eksternal terhadap Manajemen Laba pada Perusahaan Perbankan. E-Jurnal Akuntansi, 30(12),

3176-3188

RIWAYAT ARTIKEL: Artikel Masuk: 7 Juli 2020 Artikel Diterima: 14 Desember 2020

Artikel dapat diakses : https://ojs.unud.ac.id/index.php/Akuntansi/index 


\section{PENDAHULUAN}

Tujuan dari pelaporan keuangan suatu badan usaha adalah untuk menghasilkan informasi yang dapat digunakan sebagai dasar pengambilan keputusan bisnis. Hal ini sesuai dengan pernyataan Kieso et al., (2011) bahwa tujuan dari pelaporan keuangan adalah menyediakan informasi mengenai kondisi keuangan perusahaan yang berguna bagi investor, kreditur dan pengguna lainnya. Adanya manajemen laba membuat laporan keuangan yang dibuat oleh manajemen tidak menggambarkan kondisi perusahaan sebenarnya atau dapat dikatakan bahwa manajemen laba dapat mengurangi keandalan laba karena laba yang dilaporkan bias. Laba yang tidak menunjukkan informasi sebenarnya tentang kinerja manajemen akan menyesatkan pengguna laporan keuangan, karena informasi laba tidak dapat menjelaskan nilai pasar perusahaan sebenarnya atau dapat menyebabkan terjadinya kekeliruan penilaian pasar dan kekeliruan pengambilan keputusan yang diambil oleh pengguna laporan keuangan. Hal tersebut sesuai dengan pernyataan Oraby (2017) bahwa tindakan manajemen laba akan mengubah laporan keuangan yang kemungkinan dapat menyesatkan beberapa pemangku kepentingan tentang kinerja ekonomi perusahaan, karena angka akuntansi yang dilaporkan dapat mempengaruhi hasil kontrak.

Penelitian mengenai faktor-faktor yang mempengaruhi manajemen laba telah banyak dilakukan di berbagai negara, diantaranya dilakukan oleh Piot \& Janin (2007), Alzoubi (2016), Soliman \& Ragab (2014), serta Nawaiseh (2016) yang menganalisis pengaruh komite audit dan kualitas audit terhadap manajemen laba, tetapi penelitian-penelitian tersebut kurang menekankan penelitian pada audit internal sebagai salah satu mekanisme tata kelola bank. Industri perbankan memiliki regulasi yang lebih ketat dibandingkan dengan industri lainnya dan Bank Indonesia menggunakan laporan keuangan sebagai dasar dalam menentukan status suatu bank (apakah bank tersebut termasuk dalam bank yang sehat atau tidak). Oleh karena itu diperlukan suatu mekanisme yang dapat meminimalkan manajemen laba, salah satu mekanisme yang dapat digunakan adalah praktik corporate governance atau tata kelola perusahaan. Keberadaan auditor internal dan eksternal adalah bagian dari penerapan tata kelola perusahaan yang baik. Peran auditor internal dan eksternal dapat meningkatkan pengawasan terhadap perusahaan sehingga dapat menekan terjadinya tindakan yang tidak diinginkan.

Kasus manajemen laba bank yang pernah terjadi adalah seperti kasus pada Bank Bukopin, dimana pada tahun 2016 Bank Bukopin menaikkan laporan laba bersihnya dari Rp. 183,56 miliar menjadi Rp 1,08 triliun. Perubahan terbesar terjadi pada bagian pendapatan provisi dan komisi yang merupakan pendapatan dari kartu kredit. Setelah dilakukannya revisi pendapatan tersebut turun dari Rp 1,06 triliun menjadi Rp 317,88 miliar (CNBC Indonesia, 2020). Contoh kasus lain manajemen laba yang terjadi pada perusahaan perbankan adalah yang terjadi pada tahun 2002, dimana PT. Bank Lippo Tbk melakukan manipulasi laba bersih dalam laporan keuangannya, hal tersebut terungkap karena manipulasi dilakukan pada pelaporan keuangan yang telah dinyatakan "Wajar Tanpa Syarat". PT. Bank Lippo Tbk menyebutkan total aktiva perseroan yang berbeda dalam pelaporannya, pada tanggal 28 November 2002 disebutkan total aktiva perseroan adalah sebesar Rp.24 triliun dan laba bersih sebesar Rp.98 miliar, 
sedangkan pada tanggal 27 Desember 2002 disebutkan total aktiva berkurang menjadi $\mathrm{Rp} 22,8$ triliun dan mengalami rugi bersih sebesar $\mathrm{Rp}$ 1,3 triliun (Liputan6, 2020).

Teori keagenan menyatakan bahwa hubungan keagenan berada di bawah kontrak yang melibatkan principal dan agent, dimana principal mendelegasikan wewenang kepada agen untuk melakukan pengambilan keputusan. Dalam hubungan tersebut ada kecenderungan kedua belah pihak untuk memaksimalkan utilitasnya, maka terdapat kemungkinan bahwa agen tidak selalu bertindak demi kepentingan principal. Principal dapat membatasi perbedaan kepentingan tersebut dengan menetapkan insentif yang sesuai untuk agent dan dengan melakukan pemantauan agar dapat membatasi penyimpangan yang dilakukan oleh agent (Jensen \& Meckling, 1976). Penyimpangan yang ada terjadi karena perbedaan informasi yang dimiliki oleh pemilik dan agent, dimana agen memiliki informasi yang lebih tentang perusahaan daripada principal. Perbedaan informasi tersebut dianggap sebagai faktor yang dapat menyebabkan terjadinya manajemen laba. Sehingga diperlukaannya tata kelola yang baik guna menjaga kinerja perbankan. Penerapan tata kelola yang baik dapat diwujudkan melalui: kelengkapan dan pelaksanaan tugas komite dan satuan kerja yang menjalankan fungsi pengendalian internal, serta penerapan fungsi kepatuhan, audit intern dan audit ekstern (OJK, 2016).

Pada banyak perusahaan, terutama perusahaan besar, departemen audit internal sangat penting untuk memantau kinerja operasi kontrol internal secara efektif. Perusahaan menggunakan auditor internal untuk melakukan audit keuangan dan operasional. Kegiatan audit internal dapat mencegah dan mendeteksi terjadinya kegagalan atau tindakan yang tidak diinginkan yaitu dengan cara memeriksa dan mengevaluasi kontrol internal yang mengurangi risiko kecurangan. Mereka membantu dalam mendeteksi kecurangan dengan melakukan prosedur audit yang dapat mengungkapkan pelaporan keuangan yang berpotensi mengandung kecurangan dan penyalahgunaan aset (Arens et al., 2012). Auditor internal memiliki peran yang sangat penting karena memiliki pengetahuan yang lebih tentang operasi dan kontrol internal perusahaan daripada auditor eksternal, dan pengetahuan tersebut sangat penting dalam keefektifan penerapan tata kelola perusahaan. Hasil penelitian Prawitt et al., (2009) menyatakan bahwa ukuran komposit dari Internal Audit Function berpengaruh negatif dan signifikan terhadap manajemen laba. Hal tersebut sejalan dengan penelitian Sepasi et al., (2018) yang menyebutkan bahwa kualitas auditor internal yang tinggi berpengaruh signifikan terhadap laporan keuangan yang berkualitas tinggi, yang berarti bahwa hasil laporan keuangan mencerminkan keadaan perusahaan sebenarnya dan dapat menekan terjadinya manipulasi didalamnya. Untuk dapat melakukan audit pada perusahaan maka seorang auditor internal harus memiliki kemampuan atau sertifikasi yang dapat menunjang pekerjaannya sehingga dapat menekan terjadinya manajemen laba. Berdasarkan uraian tersebut maka dapat dirumuskan hipotesis sebagai berikut.

$\mathrm{H}_{1}$ : Sertifikasi auditor internal berpengaruh negatif pada manajemen laba.

Penelitian Rassas \& Kamardin (2015) menyatakan bahwa berinvestasi pada internal audit function berhubungan dengan tingginya kualitas laba yang dapat dicapai. Keberadaan audit internal pada perusahaan dapat mencegah 
terjadinya kecurangan dan penyalahgunaan, yaitu dengan cara melakukan investigasi atau pemeriksaan pada kecurangan yang telah terjadi. Laporan temuan audit/pemeriksaan internal tersebut akan membantu manajemen untuk mengambil tindakan-tindakan perbaikan sehingga akan mengurangi tindakan yang dapat merugikan perusahaan. Sehingga semakin tingginya jumlah pemeriksaan yang dilakukan auditor internal di dalam perusahaan maka akan semakin dapat menekan terjadinya manajemen laba atau perilaku yang dapat merugikan stakeholder. Berdasarkan uraian tersebut maka dapat dirumuskan hipotesis sebagai berikut.

$\mathrm{H}_{2}$ : Jumah pemeriksaan auditor internal berpengaruh negatif pada manajemen laba.

Dalam model IIA (2011) tentang tata kelola perusahaan menyebutkan bahwa IAF (Internal Audit Function) adalah salah satu dari empat landasan tata kelola perusahaan yang sangat penting, bersamaan dengan komite audit, auditor eksternal, dan manajemen. Dari keempat pilar tersebut, hanya manajemen dan IAF yang memiliki hubungan intensif/day-to-day dengan perusahaan. Apabila manajemen melakukan tindakan oportunis yang dapat merugikan para pemangku kepentingan maka auditor internal adalah pihak yang bertanggung jawab atas pemantauan day-to-day terhadap tindakan manajemen. Sehingga keberadaan auditor internal sangat berpengaruh dalam menekan terjadinya tindakan oportunis dari manajemen salah satunya adalah manajemen laba. Semakin banyaknya jumlah auditor internal maka akan dapat mencakup pengawasan day-to-day yang semakin luas dan efektif. Berdasarkan uraian tersebut maka dapat dirumuskan hipotesis sebagai berikut.

$\mathrm{H}_{3}$ : Jumlah auditor internal berpengaruh negatif pada manajemen laba.

Auditor eksternal memainkan peran penting dalam hubungan akuntabilitas, perannya adalah untuk memberikan jaminan dan keyakinan bahwa laporan keuangan mewakili situasi keuangan perusahaan sebenarnya (Barghathi et al., 2015). Penelitian Alzoubi (2016) menyatakan bahwa ukuran KAP berpengaruh signifikan terhadap manajemen laba.

Ukuran kantor akuntan publik yang lebih besar atau yang berafiliasi dengan Big 4 dilihat sebagai auditor yang memiliki kualitas audit yang lebih tinggi daripada non Big 4, dikarenakan kemampuannya dalam mendeteksi manajemen laba, dan kemungkinan besar untuk melaporkannya apabila mendeteksi adanya manajemen laba. Kantor akuntan publik yang lebih besar akan mendokumentasikan kesalahan dan penyimpangan, dan enggan mengakui pengakuan akuntansi yang meragukan (Zandi, Sadiq, \& Mohamad, 2019). Auditor Big 4 memiliki insentif yang kuat untuk menghasilkan tingkat audit yang berkualitas tinggi karena mereka memiliki lebih banyak klien dan harus mengalokasikan sumber daya yang berkualitas untuk melakukan audit (pekerjaan, teknologi, dan pelatihan) untuk melindungi klien dan mempertahankan reputasi mereka (Alzoubi, 2016). Hal tersebut sejalan dengan penelitian Nawaiseh (2016) yang menyatakan bahwa kualitas audit berpengaruh signifikan terhadap manajemen laba. Berdasarkan uraian tersebut, maka dapat dirumuskan hipotesis sebagai berikut.

$\mathrm{H}_{4}$ : Ukuran KAP berpengaruh negatif terhadap manajemen laba. 
Tenure adalah jumlah tahun atau seberapa lamanya auditor dipertahankan oleh perusahaan (Miharjo \& Hartadi, 2012). Masa penugasan audit/tenure yang lebih pendek berpengaruh pada kualitas laba yang lebih rendah, dikarenakan kurang pahamnya auditor terhadap bisnis dan industri klien (Gul et al., 2009) dan (Johnson et al., 2002). Hal tersebut didukung oleh penelitian Alzoubi (2018) dan Ghosh \& Moon (2005) yang menyatakan bahwa masa penugasan audit yang lebih panjang berpengaruh pada kualitas laba yang lebih tinggi. Untuk melakukan audit yang efektif maka dibutuhkan waktu bagi auditor untuk mengembangkan pengetahuan khusus tentang klien, sehingga dengan masa audit yang lebih lama maka auditor akan lebih memahami perusahaan klien dan dapat menghasilkan hasil audit yang lebih berkualitas. Berdasarkan uraian tersebut, maka dapat dirumuskan hipotesis sebagai berikut. $\mathrm{H}_{5}$ : Tenure KAP berpengaruh negatif terhadap manajemen laba

Penelitian Lim \& Tan (2008) menyatakan bahwa auditor spesialisasi industri lebih peduli tentang hilangnya reputasi dan paparan terhadap litigasi daripada auditor non spesialis, sehingga mereka akan menekan terjadinya manajemen laba pada perushaan klien. Hal tersebut sejalan dengan penelitian DeBoskey \& Jiang (2012) dan Lin \& Hwang (2010) yang menyatakan bahwa klien dengan auditor spesialisasi dalam suatu industri melaporkan akrual diskresioner lebih rendah daripada klien dengan auditor non spesialis. Auditor spesialis cenderung berinvestasi lebih banyak pada perekrutan dan pelatihan, teknologi informasi daripada auditor non spesialis. Berdasarkan uraian tersebut, maka dapat dirumuskan hipotesis sebagai berikut.

$\mathrm{H}_{6}$ : KAP spesialis berpengaruh negatif terhadap manajemen laba.

\section{METODE PENELITIAN}

Penelitian ini dilakukan pada perusahaan perbankan yang terdaftar di Bursa Efek Indonesia pada tahun 2014-2018. Laporan tahunan diakses dari www.idx.co.id dan website masing-masing bank. Variabel yang diamati dalam penelitian ini adalah variabel independen dan variabel dependen. Variabel dependen dalam penelitian ini adalah manajemen laba yang diukur melalui ukuran absolut dari discretionary loan loss provision. Variabel independen terdiri dari sertifikas auditor internal, jumlah pemeriksaan auditor internal, jumlah auditor internal, ukuran KAP, tenure KAP, dan spesialisasi KAP. Pemilihan sampel penelitian menggunakan teknik purposive sampling, penentuan sampelnya berdasarkan kesesuaian karakteristik dan berdasarkan kriteria tertentu. Manajemen laba diukur dengan menggunakan ukuran discretionary loan loss provision sama halnya dengan Kanagaretnam et al., (2004) dan Kwak et al., (2009), model perhitungannya adalah sebagai berikut.

LLP it = a + b1 NPL it-1 + b2 $\triangle$ NPLit + b3 $\triangle$ LOANit $+\varepsilon$

Nilai konstanta dan koefisien regeresi tiap variabel yang diperoleh digunakan untuk menentukan nilai non discretionary loan loss provisions.

NDLLP it $=\mathrm{a}+\mathrm{b} 1$ NPL it-1 + b2 $\triangle$ NPLit + b3 $\triangle$ LOANit

Selanjutnya untuk mendapatkan nilai discretionary loan loss provisions adalah dengan cara mencari selisih antara loan loss provisions dengan non discretionary loan loss provisions.

DLLP it $=$ LLP it - NDLLP it 
Keterangan:

LLP = Total LLP/CKPN dibagi dengan saldo awal kredit $\left(\operatorname{loan}_{\mathrm{t}-1)}\right.$

NPL it-1 = NPL $\quad=$ dibagi dengan saldo awal kredit

$\triangle$ NPLit $\quad=$ Selisih NPL $L_{\mathrm{t}}$ dan NPL $\mathrm{L}_{\mathrm{t}-1} \mathrm{~d}$ dibagi saldo awal kredit

$\triangle$ LOANit $\quad=$ Saldo kredit tahun $\mathrm{t}-$ Loan $_{\mathrm{t}-1}$ dibagi saldo awal kredit

NDLLP it $\quad=$ non discretionary loan loss provision

DLLP it = discretionary loan loss provision

Tabel 1. Pengukuran Variabel Independen dan Variabel Kontrol

\begin{tabular}{lll}
\hline No. & Variabel & Pengukuran \\
\hline 1. & Sertifikasi & jumlah auditorinternalyangmemilikisertifikasi auditorinternal \\
& Auditor & jumlah pegawai auditorinternal \\
& Internal & $100 \%$
\end{tabular}

(Prawitt et al., 2009)

2. Jumlah total kegiatan audit atau pemeriksaan yang dilaksanakan oleh

Pemeriksaan Satuan Kerja Audit Internal pada satu tahun

3. Jumlah Total pegawai Satuan Kerja Audit Internal dalam satu tahun

Auditor

Internal (Prawitt et al., 2009)

4. Ukuran KAP yang berafiliasi dengan Big 4 bernilai 1, dan 0 untuk KAP selainnya

(Idris et al., 2018)

5. tenure KAP jumlah tahun bertutur-turut KAP melakukan audit terhadap perusahaan

(Gul et al., 2009)

6. KAP

spesialis

Jumlah emiten yang diaudit oleh KAP

Jumlah seluruh emiten pada satu industri $\mathrm{X} 100 \%$

Jika hasilnya sama dengan di atas $15 \%$ maka diberi nilai 1 , dan 0 untuk selainnya

7. NPL

Non Performing Loan $=\frac{\text { Kredit Bermasalah }}{\text { Total Kredit }} \times 100 \%$

(Darmawi, 2011)

8. $\quad$ EBTP

$$
\mathrm{EBTP}=\frac{\text { Earning before tax and provision }}{\text { TOTAL ASET }}
$$

(Xu et al., 2019)

9. Leverage

(Kasmir, 2013)

$$
\text { Leverage }=\frac{\text { Total Utang }}{\text { Total Aset }}
$$

10. Firm Size

$$
\text { Ukuran Perusahaan }=\text { Ln }(\text { Total Aktiva })
$$

(Hartono, 2008)

Sumber: Data Penelitian, 2020

Metode analisis data yang digunakan dalam penelitian ini adalah analisis regresi berganda. Analisis ini dipergunakan untuk mengetahui dan memperoleh gambaran mengenai pengaruh Kualitas audit dan audit internal terhadap manajemen laba pada perusahaan sektor perbankan yang terdaftar di Bursa Efek Indonesia tahun 2014-2018. Model persamaan yang digunakan untuk menguji hipotesis dalam penelitian ini sebagai berikut. 
$\mathrm{DLLP}=\alpha_{0}+\beta 1$ SERT $+\beta 2 \mathrm{INSPECT}+\beta 3$ SIZEINT $+\beta 4$ SIZEKAP $+\beta 5$ TENURE + $\beta 6$ PPECIALIST $+\beta 7 \mathrm{NPL}+\beta 8 \mathrm{EBTP}+\beta$ LEV $+\beta 10 \mathrm{FSIZE}$

Keterangan:

$\begin{array}{ll}\alpha_{0} & =\text { konstanta } \\ \text { DLLP } & =\text { discretionary loan loss provision/manajemen laba } \\ \text { SERT } & =\text { Rasio sertifikasi audit internal } \\ \text { INSPECT } & =\text { Jumlah realisasi pemeriksaan audit oleh auditor internal } \\ \text { SIZEINT } & =\text { Jumlah karyawan satuan kerja auditor internal } \\ \text { SIZEKAP } & =\text { Ukuran auditor eksternal yang berafiliasi Big } 4 \\ \text { TENURE } & =\text { Masa perikatan dengan kantor akuntan publik } \\ \text { SPECIALIST } & =\text { Auditor spesialis pada tahun } \mathrm{t} \\ \text { NPL } & =\text { Non performing loan } \\ \text { EBTP } & =\text { Pendapatan sebelum pajak dan provisi } \\ \text { LEV } & =\text { leverage } \\ \text { FSIZE } & =\text { Ukuran perusahaan }\end{array}$

HASIL DAN PEMBAHASAN

Populasi penelitian adalah bank umum konvensional yang terdaftar di Bursa Efek Indonesia tahun 2014-2018 yang mencakup 41 perusahaan perbankan. Perusahaan yang digunakan dalam penelitian ini sejumlah 22 perusahaan perbankan yang menyampaikan informasi secara lengkap terkait variabel yang diteliti pada tahun 2014-2018.

Tabel 2. Statistik Deskriptif

\begin{tabular}{llcccc}
\hline & $\mathrm{N}$ & Minimum & Maximum & Mean & Std. Deviation \\
\hline DLLP & 109 & 0,00 & 0,07 & 0,0093 & 0,00850 \\
SERT & 109 & 0,01 & 0,93 & 0,3114 & 0,21432 \\
INSPECT & 109 & 17,00 & 856,00 & 193,9266 & 173,15149 \\
SIZEINT & 109 & 11,00 & 726,00 & 114,367 & 126,18576 \\
SIZEKAP & 109 & 0,00 & 1,00 & 0,7982 & 0,40322 \\
TENURE & 109 & 1,00 & 9,00 & 5,5505 & 2,67182 \\
SPEC & 109 & 0,00 & 1,00 & 0,6239 & 0,48666 \\
NPL & 109 & 0,25 & 8,54 & 2,7731 & 1,38863 \\
EBTP & 109 & $-0,04$ & 0,08 & 0,0179 & 0,01707 \\
LEV & 109 & 0,74 & 0,94 & 0,8452 & 0,04517 \\
FSIZE & 109 & 15,46 & 20,91 & 18,1197 & 1,41878 \\
Valid N (listwise) & & & & & \\
\hline
\end{tabular}

Sumber: Data Penelitian, 2020

Berdasarkan hasil yang tertera pada Tabel 2, dapat dilihat bahwa manajemen laba yang diukur melalui ukuran absolute DLLP memiliki nilai minimum sebesar 0,00 dan nilai maksimum sebesar 0,07. Rata-rata dari DLLP adalah 0,0093 dengan standar deviasi sebesar 0,00850. SERT memiliki nilai minimum sebesar 0,01 dan nilai maksimum sebesar 0,93, dengan mean dan standar deviasi masing- masing 0,3114 dan 0,21432. INSPECT memiliki nilai min sebesar 17,00 dan max sebesar 856,00 dengan mean sebesar 193,9266 dan standar deviasi sebesar 173,15149. SIZEINT memiliki nilai min sebesar 11,00 dan nilai max sebesar 726,00 dengan mean sebesar 114,367 dan standar deviasi sebesar 126,18576 . SIZEKAP memiliki nilai min sebesar 0,00 dan nilai max sebesar 1,00 dengan nilai mean sebesar 0,7982 dan standar deviasi sebesar 0,40322. TENURE 
memiliki nilai min sebesar 1,00 dan nilai max sebesar 9,00 dengan mean sebesar 5,5505 dan standar deviasi sebesar 2,67182. SPEC memiliki nilai min sebesar 0,00 dan nilai max sebesar 1,00 dengan nilai mean sebesar 0,6239 dan standar deviasi sebesar 0,48666.

Tabel 3. Hasil Analisis Regresi Linier Berganda

\begin{tabular}{|c|c|c|c|c|c|}
\hline \multirow[t]{2}{*}{ Model } & \multicolumn{2}{|c|}{$\begin{array}{l}\text { Unstandardized } \\
\text { Coefficient }\end{array}$} & $\begin{array}{l}\text { Standardized } \\
\text { Coefficient }\end{array}$ & \multirow[t]{2}{*}{$\mathrm{t}$} & \multirow[t]{2}{*}{ Sig. } \\
\hline & B & Std. Error & Beta & & \\
\hline (Constant) & 0,43 & 0,20 & & 2,205 & 0,030 \\
\hline SERT & 0,001 & 0,004 & 0,022 & 0,217 & 0,829 \\
\hline INSPECT & $2,646 \mathrm{E}-6$ & 0,000 & 0,054 & 0,535 & 0,594 \\
\hline SIZEINT & $-1,277 \mathrm{E}-5$ & 0,000 & $-0,190$ & $-1,694$ & 0,093 \\
\hline SIZEKAP & 0,007 & 0,003 & 0,331 & 2,452 & 0,016 \\
\hline TENURE & $-0,001$ & 0,000 & $-0,440$ & $-3,628$ & 0.000 \\
\hline SPEC & $-0,003$ & 0,002 & $-0,171$ & $-1,384$ & 0,170 \\
\hline NPL & 0,000 & 0,001 & $-0,052$ & $-0,499$ & 0,619 \\
\hline EBTP & $-0,181$ & 0,060 & $-0,364$ & $-3,004$ & 0,003 \\
\hline LEV & $-0,040$ & 0,020 & $-0,214$ & $-2,061$ & 0,042 \\
\hline FSIZE & 0,000 & 0,001 & 0,082 & 0,581 & 0,563 \\
\hline
\end{tabular}

Sumber: Data Penelitian, 2020

Berdasarkan hasil analisis regresi linier berganda pada Tabel 3, maka persamaan regresi yang digunakan dalam penelitian ini adalah sebagai berikut $Y=0,43+0,001 X_{1}+0,000002646 X_{2}-0,00001277 X_{3}+0,007 X_{4}-0,001 X_{5}-0,003 X_{6}+$ $0.000 X_{7}-0,181 X_{8}-0,040 X_{9}+0,000 X_{10}$

Keterangan:

$\mathrm{Y}=$ Manajemen Laba

$\mathrm{X}_{1}=$ Sertifikasi auditor internal

$\mathrm{X}_{2}=$ Jumlah pemeriksaan auditor internal

$\mathrm{X}_{3}=$ Jumlah karyawan auditor internal

$\mathrm{X}_{4}=$ Ukuran KAP

$\mathrm{X}_{5}=$ tenure $\mathrm{KAP}$

$\mathrm{X}_{6}=$ spesialisasi $\mathrm{KAP}$

$\mathrm{X}_{7}=$ Non Performing Loan

$\mathrm{X}_{8}=$ Earning Before Tax and Provision

$\mathrm{X}_{9}=$ Leveraga

$\mathrm{X}_{10}=$ Ukuran perusahaan

Berdasarkan persamaan regresi tersebut, maka dapat dijelaskan beberapa hal sebagai berikut. Nilai konstanta sebesar 0,043 menunjukkan apabila variabel independen yang terdiri dari $X_{1}, X_{2}, X_{3}, X_{4}, X_{5}$, dan $X_{6}$ sama dengan nol, maka manajemen laba yang terjadi sebesar 0,043 . Nilai koefisien $X_{3}$ sebesar $-0,00001277$ menunjukkan bahwa jika jumlah auditor internal bertambah 1 satuan maka manajemen laba akan berubah sebesar -0,00001277 satuan dengan asumsi variabel lainnya konstan. Nilai koefisien $X_{4}$ sebesar 0,007 yang menunjukkan bahwa jika ukuran KAP bertambah 1 satuan, maka manajemen laba akan berubah sebesar 0,007. Nilai koefisien $X_{5}$ sebesar -0,001 menunjukkan bahwa jika tenure KAP bertambah 1 satuan, maka manajemen laba akan berubah sebesar 0,001 satuan dengan asumsi variabel lainnya konstan. 
Tabel 4. Hasil Uji Statistik F (Uji F)

\begin{tabular}{llllll}
\hline Model & Sum of Squares & $d f$ & Mean Square & F & Sig. \\
\hline Regression & 0,002 & 10 & 0,000 & 3,597 & 0,000 \\
Residual & 0,006 & 98 & 0,000 & & \\
Total & 0,008 & 108 & & & \\
\hline
\end{tabular}

Sumber: Data Penelitian, 2020

Berdasarkan Tabel 4, Nilai signifikansi lebih kecil dari $\alpha=0,1$ yang berarti bahwa variabel independen signifikan secara bersama-sama terhadap variabel dependen, sehingga dapat disimpulkan bahwa model tersebut layak diteliti.

Tabel 5. Hasil Koefisien Determinasi (R2)

\begin{tabular}{lllll}
\hline Model & $\mathrm{R}$ & $\mathrm{R}$ Square & $\begin{array}{l}\text { Adjusted } \mathrm{R} \\
\text { Squared }\end{array}$ & $\begin{array}{l}\text { Std. Error of } \\
\text { the Estimate }\end{array}$ \\
\hline & 0,518 & 0,268 & 0,194 & 0,00763 \\
\hline
\end{tabular}

Sumber: Data Penelitian, 2020

Dapat dilihat dari Tabel 5, nilai $\mathrm{R}^{2}$ sebesar 0,268 atau 26,8\% variasi dari variabel dependen (manajemen laba) dapat dijelaskan oleh variasi dari variabel independen yang terdiri dari, sertifikasi auditor internal, jumlah pemeriksaan auditor internal, jumlah audito internal, ukuran $\mathrm{KAP}$, tenure $\mathrm{KAP}$, dan spesialisasi KAP.

Pada Tabel 3 menunjukkan bahwa hasil pengujian hipotesis menolak $\mathrm{H}_{1}$ dan $\mathrm{H}_{2}$. Dimana nilai sig. masing-masing variabel SERT dan INSPECT adalah sebesar 0.829 dan 0,594 yang lebih besar dari 0,1. Hal tersebut menunjukkan bahwa sertifikasi dan jumlah pemeriksaan auditor internal tidak berpengaruh atau tidak dapat menekan terjadinya manajemen laba. Persentase sertifikasi yang dimiliki auditor internal memang menunjukkan kompetensi yang dimiliki oleh auditor internal, tetapi apabila peran yang dilaksanakan oleh auditor internal tidak dijalankan secara semestinya maka sertifikasi yang ada tidak berpengaruh signifikan terhadap manajemen laba. Jumlah pemeriksaan auditor internal juga tidak berpengaruh terhadap manajemen laba. Apabila auditor internal hanya meningkatkan jumlah pemeriksaan atau hanya menekankan pada kuantitas pemeriksaan saja maka hal tersebut tidak akan efektif untuk menekan terjadinya tindakan manajemen laba.

Hipotesis ketiga penelitian ini menyatakan bahwa jumlah auditor internal berpengaruh negatif pada manajemen laba. Hasil yang diperoleh dari pengolahan data yang telah dilakukan adalah $\mathrm{H}_{3}$ diterima, yaitu jumlah auditor internal berpengaruh negatif terhadap manajemen laba. Nilai signifikansi dari ukuran auditor internal $\left(X_{3}\right)$ sebesar 0,093, dimana nilainya lebih kecil dari 0,1. Hasil penelitian tersebut sejalan dengan penelitian Prawitt et al., (2009) yang menyatakan bahwa ukuran komposit auditor internal yang didalamnya terdapat jumlah auditor internal berpengaruh negatif dan signifikan terhadap manajemen laba. Auditor internal memiliki peran yang sangat penting karena memiliki pengetahuan yang lebih tentang operasi dan kontrol internal perusahaan daripada auditor eksternal, dan pengetahuan tersebut sangat penting untuk tata kelola perusahaan yang efektif. auditor internal adalah pihak yang bertanggung jawab atas pemantauan day-to-day terhadap tindakan manajemen. Sehingga keberadaan auditor internal sangat berpengaruh dalam menekan terjadinya tindakan oportunis dari manajemen salah satunya adalah manajemen laba. 
Jumlah karyawan auditor yang lebih banyak akan dapat melakukan pengawasan yang lebih efektif terhadap perusahaan.

Hipotesis keempat menyatakan bahwa ukuran KAP berpengaruh negatif pada manajemen laba. Hasil penelitian menunjukkan nilai signifikansi sebesar 0,016 dan lebih rendah dari $\alpha=0,1$ serta nilai koefisien regresi sebesar 0,007 . Hal ini menunjukkan bahwa ukuran KAP berpengaruh positif terhadap manajemen laba, sehingga hipotesis $\mathrm{H}_{4}$ ditolak. Hal tersebut sesuai dengan hasil penelitian (Rahmawati et al., 2017) yang menyatakan bahwa ukuran KAP berpengaruh positif signifikan terhadap manajemen laba. Ukuran KAP yang besar tidak terbukti dapat membatasi perilaku manajemen laba yang dilakukan perusahaan dan cenderung meningkatkan perilaku manajemen laba. Hal tersebut dikarenakan ukuran KAP digunakan oleh perusahaan hanya untuk menarik investor. Tingkat signifikansi yang positif dapat disebabkan oleh auditor yang termasuk Big4 lebih kompeten dan profesional dibandingkan auditor yang bukan Big4, sehingga auditor dengan ukuran yang lebih besar memiliki pengetahuan lebih banyak tentang cara mendeteksi dan memanipulasi laporan keuangan maupun tindakan manajemen laba.

Hipotesis kelima menyatakan bahwa tenure KAP berpengaruh negatif terhadap manajemen laba. Hasil pengujian menunjukkan nilai signifikansi sebesar 0,000 dan lebih rendah daripada taraf signifikansi dengan koefisien sebesar -0,001. Hal tersebut menunjukkan bahwa tenure KAP berpengaruh negatif terhadap manajemen laba, sehingga $\mathrm{H}_{5}$ diterima. Hasil tersebut menunjukkan bahwa tenure KAP yang lebih lama mampu menekan terjadinya manajemen laba perusahaan perbankan. Hasil penelitian tersebut sesuai dengan penelitian Gul et al. (2009) dan Johnson et al. (2002) menunjukkan bahwa masa penugasan audit/tenure yang lebih pendek berpengaruh pada kualitas laba yang lebih rendah, dikarenakan kurang pahamnya auditor terhadap bisnis dan industri klien. Bertambahnya masa penugasan audit atau masa penugasan audit yang lebih panjang membuat auditor eksternal lebih memahami usaha klien dan sehingga dapat mengurangi atau menekan terjadinya manajemen laba yang terjadi, karena semakin teliti pekerjaan auditor berarti perusahaan klien harus melaporkan kinerja usaha yang sesuai dengan keadaan sebenarnya.

Hipotesis keenam menyatakan bahwa spesialisasi auditor berpengaruh negatif terhadap manajemen laba. Pengujian menghasilkan nilai koefisien sebesar -0,003 dan nilai signifikansi sebesar 0,170 yang lebih besar dari taraf signifikansi. Hasil tersebut berarti $\mathrm{H}_{6}$ ditolak karena nilai sig lebih besar dari 0,1. Sehingga spesialisasi auditor pada industri perbankan tidak terbukti dapat membatasi manajemen laba yang dilakukan oleh perusahaan perbankan. Spesialisasi auditor memiliki pengaruh negatif terhadap manajemen laba tetapi pengaruhnya tidak signifikan. Hal ini berarti bahwa audit yang dilakukan oleh KAP spesialis tidak menjadi jaminan dapat memberikan kualitas audit yang lebih tinggi (Ginting, 2010). KAP spesialis memang memiliki pangsa pasar yang lebih besar daripada KAP non spesialis dalam industri, tetapi tidak menuntut kemungkinan bahwa akuntan publik memiliki kelemahan dalam melakukan review kesesuaian laporan keuangan dengan standar akuntansi yang ada. 


\section{SIMPULAN}

Hasil dari analisis data penelitian menunjukkan bahwa manajemen laba dapat dipengaruhi oleh jumlah auditor internal, tenure KAP dan ukuran KAP. Jumlah auditor internal yang lebih banyak dapat menekan terjadinya manajemen laba, karena auditor internal dapat melakukan pengawasan yang lebih efisien dan intensif. Masa penugasan audit yang lebih lama juga berpengaruh negatif terhadap manajemen laba. Semakin lama auditor melakukan audit terhadap suatu perusahaan maka auditor akan semakin memahami bisnis dan industri perusahaan, sehingga perusahaan harus menyampaikan laporan yang sesuai dengan keadaan yang sebenarnya. Ukuran KAP berpengaruh positif terhadap manajemen laba. Hal tersebut dikarenakan auditor dengan ukuran yang lebih besar memiliki pengetahuan lebih banyak tentang cara mendeteksi dan memanipulasi laporan keuangan maupun tindakan manajemen laba dan perusahaan hanya menggunakan ukuran KAP untuk menarik investor. Sertifikasi dan jumlah pemeriksaan auditor internal tidak berpengaruh terhadap manajemen laba. Jumlah sertifikasi dan pemeriksaan yang ada hanya menunjukkan kuantitasnya saja dan perlu adanya peningkatan efektifitas peran auditor internal di dalam perusahaan. Spesialisasi audit juga tidak berpengaruh terhadap manajemen laba karena akuntan publik memiliki kelemahan dalam melakukan review kesesuaian laporan keuangan dengan standar akuntansi yang ada.

Penelitian ini memiliki keterbatasan, yaitu sampel yang digunakan dalam penelitian ini perlu ditingkatkan. Data auditor internal pada perusahaan perbankan belum disampaikan secara menyeluruh, sehingga mungkin dapat menggunakan konstruk variabel lain yang dapat digunakan sebagai faktor yang dapat mempengaruhi manajemen laba baik dari segi pengawasan eksternal, internal maupun variabel lainnya. Bagi perusahaan, penelitian ini diharapkan dapat memberikan masukan atau tambahan informasi mengenai pentingnya mekanisme pengawasan internal dan eksternal terhadap manajemen laba, sehingga perusahaan dapat menekan terjadinya manajeme laba atau tindakan yang dapat merugikan para investor dan pengguna laporan keuangan.

\section{REFERENSI}

Al-Rassas, A. H., \& Kamardin, H. (2015). Internal and external audit attributes, audit committee characteristics, ownership concentration and earnings quality: Evidence from Malaysia. Mediterranean Journal of Social Sciences, 6(3), 458. https://doi.org/10.5901/mjss.2015.v6n3p458

Alzoubi, E. S. S. (2016). Audit quality and earnings management: evidence from Jordan. Journal of Applied Accounting Research. https:// doi.org/10.1016/j.intaccaudtax.2017.12.001

Alzoubi, E. S. S. (2018). Audit quality, debt financing, and earnings management: Evidence from Jordan. Journal of International Accounting, Auditing and Taxation, 30, 69-84. https:/ / doi.org/10.1016/j.intaccaudtax.2017.12.001

Arens, A. A., Elder, R. J., \& Mark, B. (2012). Auditing and assurance services: an integrated approach. Boston: Prentice Hall.

Barghathi, Y., Collison, D., \& Crawford, L. (2015). Earnings Management and the Role of the External Auditor. Financial Reporting and Business Communication 
Nineteenth Annual Conference.

CNBC Indonesia. (2018). Drama Bank Bukopin: Kartu Kredit Modifikasi dan Rights Issue. Diambil 3 Februari 2020, dari https://www.cnbcindonesia.com/market/20180427144303-1712810/drama-bank-bukopin-kartu-kredit-modifikasi-dan-rights-issue

Darmawi, H. (2011). Manajemen perbankan. Jakarta: Bumi Aksara.

DeBoskey, D. G., \& Jiang, W. (2012). Earnings management and auditor specialization in the post-sox era: An examination of the banking industry. Journal of Banking \& Finance, 36(2), 613-623. https:// doi.org/10.1016/j.jbankfin.2011.09.007

Ghosh, A., \& Moon, D. (2005). Auditor tenure and perceptions of audit quality. The accounting $\quad$ review, 80(2), 585-612. https:/ / doi.org/10.2308/accr.2005.80.2.585

Ginting, J. N. (2010). Pengaruh Struktur Kepemilikan dan Kualitas Audit terhadap Manajemen Laba.

Gul, F. A., Fung, S. Y. K., \& Jaggi, B. (2009). Earnings quality: Some evidence on the role of auditor tenure and auditors' industry expertise. Journal of accounting and Economics, 47(3), 265-287. https:// doi.org/10.1016/j.jacceco.2009.03.001

Hartono, J. (2008). Teori portofolio dan analisis investasi. Yogyakarta: BPFE.

Idris, M. I., Siam, Y. I. A., \& Ahmad, A. L. (2018). The impact of external auditor size on the relationship between audit committee effectiveness and earnings management. Investment management and financial innovations, (15, Iss. 3), 122-130. https:/ / doi.org/10.21511/imfi.15(3).2018.10

IIA. (2011). International Professional Practices Framework. USA: The Institute of Internal Auditor Inc.

Jensen, M. C., \& Meckling, W. H. (1976). Agency Costs and the Theory of the Firm. Journal of financial economics, 3(4), 305-360. https:// doi.org/10.1111/j.1540-6288.1986.tb00759.x

Johnson, V. E., Khurana, I. K., \& Reynolds, J. K. (2002). Audit- firm tenure and the quality of financial reports. Contemporary accounting research, 19(4), 637660. https:// doi.org/10.1506/LLTH-JXQV-8CEW-8MXD

Kanagaretnam, K., Lobo, G. J., \& Mathieu, R. (2004). Earnings management to reduce earnings variability: evidence from bank loan loss provisions. Review of Accounting and Finance. https://doi.org/10.1108/eb043399

Kasmir. (2013). Analisis Laporan Keuangan. Jakarta: PT. Raja Grafindo Persada.

Kieso, D. E., Weygandt, J. J., \& Warfield, T. D. (2011). Intermediate Accounting, Working Papers (Vol. 2). John Wiley \& Sons.

Kwak, W., Lee, H.-Y., \& Eldridge, S. W. (2009). Earnings management by Japanese bank managers using discretionary loan loss provisions. Review of Pacific Basin Financial Markets and Policies, 12(01), 1-26. https:/ / doi.org/10.1142/S0219091509001526

Lim, C., \& Tan, H. (2008). Non- audit service fees and audit quality: The impact of auditor specialization. Journal of accounting research, 46(1), 199-246. https:// doi.org/10.1111/j.1475-679X.2007.00266.x

Lin, J. W., \& Hwang, M. I. (2010). Audit quality, corporate governance, and earnings management: A meta- analysis. International Journal of Auditing, 
14(1), 57-77. https://doi.org/10.1111/j.1099-1123.2009.00403.x

Liputan6. (n.d.). BI dan BEJ Membahas Kasus Bank Lippo. Diambil 3 Februari 2020, dari https://www.liputan6.com/news/read/49134/bi-dan-bejmembahas-kasus-bank-lippo\#

Miharjo, S., \& Hartadi, B. (2012). Does auditor tenure reduce audit quality? Gadjah Mada International Journal of Business, 14(3), 303-315. https://doi.org/10.22146/gamaijb.5478

Nawaiseh, M. E. (2016a). Can earnings management be influenced by audit quality. International Journal of Finance and Accounting, 5(4), 209-219. https:// doi.org/10.5923/j.ijfa.20160504.06

Nawaiseh, M. E. (2016b). Impact of external audit quality on earnings management by banking firms: Evidence from Jordan. Current Journal of Applied Science and Technology, 1-14. https:// doi.org/10.9734/bjast/2016/19796

Oraby, S. A. (2017). The impact of earnings management strategies on accounting information relevance. International Journal of Business and Social Science, 8(4), 125-135. https:// doi.org/10.1016/j.jacceco.2009.01.001

Otoritas Jasa Keuangan. (2016). 55/POJK. 03/2016. Tentang Penerapan Tata Kelola Bagi Bank Umum.

Piot, C., \& Janin, R. (2007). External auditors, audit committees and earnings management in France. European accounting review, 16(2), 429-454. https:// doi.org/10.1080/09638180701391030

Prawitt, D. F., Smith, J. L., \& Wood, D. A. (2009). Internal audit quality and earnings management. The accounting review, 84(4), 1255-1280. https:// doi.org/10.2308/accr.2009.84.4.1255

Rahmawati, M., Dewi, V. S., \& Hikmah, S. N. (2017). Pengaruh Kualitas Auditor dan Corporate Governance terhadap Manajemen Laba (Studi Empiris pada Perusahaan Manufaktur yang Terdaftar di Bursa Efek Indonesia Periode 2011-2016). URECOL, 459-474.

Sepasi, S., Dianati Deilami, Z., \& Manzari Tavakoli, S. (2018). Internal Audit, Board of Directors and Financial Reporting Quality. International Journal of Finance \& Managerial Accounting, 2(8), 63-75. https://doi.org/10.1108/MAJ06-2013-0886

Soliman, M. M., \& Ragab, A. A. (2014). Audit committee effectiveness, audit quality and earnings management: an empirical study of the listed companies in Egypt. Research Journal of Finance and Accounting, 5(2), 155-166. https:// doi.org/10.22495/cocv11i2c3p4

Xu, Z., Choo, K.-K. R., Dehghantanha, A., Parizi, R., \& Hammoudeh, M. (2019). Cyber Security Intelligence and Analytics (Vol. 928). Springer.

Zandi, G., Sadiq, M., \& Mohamad, S. (2019). Big-four auditors and financial reporting quality: evidence from Pakistan. Humanities $\mathcal{E}$ Social Sciences Reviews, 7(2), 369-375. https://doi.org/10.18510/hssr.2019.7243 